\title{
Nigeria Language Policy: A Conflict of Interest
}

\author{
Biale Zua \\ Tennessee State University \\ 3500 John A Merritt Blvd, Nashville, TN 37209, United States
}

\section{What is Language Policy?}

Language policy has often been defined as what a government does either officially through legislation, court decision, or policy to determine how languages are used in public contexts (Crawford, 2017). This definition makes language policy a top-to-bottom movement on how languages should be used within amultilingual society. However, Johnson (2013) argues that not all language policies are enacted by the government.Some language policies are made bygrassroot organizations. Thus, this makes the language policy a bottom-to-top movement. Johnson (2013) concludes that not all language policies are carefully planned and intentional.

Whether language policy is top-to-bottom or vice versa, language policy is designed to favor some language(s) and discourage the use of other languagesin a multilingual society.It is the deliberate effort to influence the status of one language above the other. It includes the implementation of the selected language as a medium of instruction or a subject to be taught in schools. Hence, Tondo (2017) defines language policy as a binding language guide which is meant to be enforced by the society that formulates it through a political process. Robin \& Jernudd (1971) definedlanguage policyas a deliberate act aimed at solving a problem within a social context.

The implementation of a language policy is often associated with language planning. Sometimes, both terms are used interchangeablybecause language planning and language policy are inseparable.Robin \& Jernudd (1971) defined language planning as a deliberate language change. Changes in the system of language code, speaking or both are planned by organizations that are established for such purposes. The most frequently quoted definition oflanguage planning is Cooper's definition. Language planning is the deliberate effort to influence the behavior of others with respect to the acquisition, structure, and functional allocation of their language codes (Cooper, 1989).Language planninginvolves the implementation of the language policy or decision. Fisher (1973) defined language planning as the organized pursuit of solutions to language problems. Language planning involves different stages such as corpus planning, status planning, and acquisition planning.

Corpus planning is the intervention in the forms of language (Ibekwe, 2006). Forms of a language include phonology, morphology, syntax, semantics, and pragmatics. It involves appropriate usage. Corpus planning creates new words and expressions. It adds new meanings to existing old words. It involves the selection of the norms and codification. The aim of corpus planning is to develop resources in the language, so that it becomes an appropriate medium of communication for modern topics and forms of discourse. Corpus planning is aimed at equipping the language with terminology needed for use in administration, education, justice, business, and wider communication. This includes writing of the grammar and spelling standardization. Not all Nigerian languages have standard orthographies.Status planning deals with the choice of one language over the other languages. It refers to the sociopolitical status assigned to a language. It refers to the modifications in the social role of a language (Cobarrubias, 1983). For example, the government of Nigeria elevated the status of three languages as the national language which are Hausa, Yoruba, and Igbo. These languages were placed above other indigenous languages. Acquisition planning relates to the teaching and learning of the language that is chosen as the medium of instruction in schools. It involves the deliberate efforts to influence the number of users and the distribution of languages and literacies. This is achieved by creating opportunities or incentives to learn the elevated languages. It is usually done by government officials or private institutions that control textbooks and dictionaries.

\section{Multilingualism in Nigeria}

Before the colonization of the geographical entity now known as Nigeria, multilingualism had long existed. The geographical area of Nigeria is 356,667 square miles with a population density of 85.32 people per square miles (Worldometers, 2019). The current population of Nigeria in 2019 is $\mathbf{2 0 0 , 8 4 2 , 6 1 4}$ with 104,282,822 (51.9 per cent)of the population living in urban areas (Worldometers, 2019).It existed as different ethnic groups with different culturesand the people speaking over 528 languages(Gordon, 2017). 
With the colonization of this geographical entity, the different ethnic groups were brought together as Nigeria under British rule. This occurred at the Berlin Conference in 1884 in Germany. The Berlin Conference was wherethe African continent, comprising of different ethnic groups,was partitioned among European countries.European countriesapportionedto themselves the areasthey occupied and controlled. Thus, some ethnic groups ended up under French Rule and some ended up under British, German, or Belgian rule. The area, called Nigeriatoday,ended up under British rule. With colonialism, came a century of exploitation of not just the Nigeria people, but the African people. The natural resources of this continent were exploited. It was a period of the denial of their language rights. English language became the official language of government, education, and inter-ethnic communication. This mandate was enactedbecause of bringingheterogeneous groups, with different languages and cultures, under one umbrella.

With the attainment of independence in 1960, the choice of a national language became a problem. Language planning and language policy became necessary as each linguistic group, especially the minorities, struggled for identity and linguistic right within the multilingual and multicultural society. Identification with a language is significant to culture. Language and culture are inseparable. In a multilingual and multicultural society, like Nigeria, language rights are crucial because language correlates with power.

Planning and policies were highly political and influenced by religion. Consequently, language planning was geared towards the rejection of English language in certain areas and theelevation of certain Nigeria languages to official status.Becauselanguage policy is political, Akinnaso (1990), stated that language politics in Nigeria has been a struggle against two opposing forces. One struggle isagainst the vestiges of colonialismand the other against the domination of larger language groups who are against ethnic minorities.As stated by Bamgbose (1971), language planning in Nigeria has assigned special statuses to specific languages while at the same time developing other languages so they could be used in education, administration, and other areas. The languages that were assigned special statuses were Hausa, Yoruba, and Igbo.

\section{Language in Education Policy}

Nigeria did not have a consciously planned language policy that is national in scope until 1977 when some aspects of language teaching in schools were introduced in the National Policy on Education (NPE). The policy was revised in 1981 and 1985 (Akinnaso, 1990). This is not peculiar to Nigeria alone. The United States, for example, has not had a planned language policy. However, there were ad hoc responses formed to meet immediate needs due to the changing demographics of the US population (Crawford, 2017).Educationis one domain where Nigerian government has made deliberate effort and decisions to influence the use and status of language. The role of language in education policy is to ensure that any language used for instruction facilitates real development. Such policies are not made to hinder the purpose of education, but to facilitate teaching and learning. These decisions have resulted in different policies, curriculum and assessment documents, and other official documents that affect language teaching profession from theory to practice. Three languages Hausa, Yoruba, and Igbo were elevated to the status of major languages. Students were expected to study one ofthese languages in addition to their Mother Tongue. This was done to foster unity in the country and reject the colonial language of English as a national language.

The use of Mother Tongue in school's dates to the colonial era when missionaries and colonial government favored the use of Mother Tongue in the primary schools and English in the secondary schools. According to Ayankanmi (1966,)mission schools provided a steady stream of "educated Africans" that filled the lower levels of the colonial administration. Despite the government's decision about the use of these major Nigerian languages in schools, the implementation of this decision has been challenging and frustrating.Ethnicminority groups believe that the decision excluded their languages and threatened their very existence.

The codification of language policy in Nigeria could be traced back to the Colonial Era.In 1919, the recommendation of the Phelps-Stokes Commission to use theMother Tongueas the medium of instruction in the lower primary was accepted. English was retained as the medium of instruction in the higher primary and secondary schools (Akinnaso, 1990).The Phelps-Stokes Commission was a private, missionary group that was funded while calling for partnership between government and missions. The recommendation of the Phelps-Stokes Commission was upheld in subsequent policies on language education. By the 1940s and 1950s, when natives began to participate in government, more attention was drawn to the use of Mother Tongue in schools.

In 1960, when Nigeria became independent, Hausa, Yoruba, and Igbo had emerged as regional languages. They were dominant in the North, West, and Eastern part of the country (Akinnaso, 1990). These languages were fully established as school subjects and medium of instruction in the lower primary content area.Other indigenous languages were established as method of instruction in schools to varying degrees such as Efik, Ibiblio, Kanuri, Ijaw, Tiv, Edo, Nupe, Igala, and Idoma.Other languages were neglected due to the insignificant number of native speakers and lack of written orthographies 
The language provisions in the National Policy of Education are as follows:

\section{Section 1:8}

"In addition to appreciating the importance of language in the educational process, and as a means of preserving the peoples' culture, the Government considers it to be in the interest of national unity that each child should be encouraged to learn one of the three major languages other than his Mother Tongue. In this connection, the government considers the three major languages in Nigeria to be Hausa, Yoruba, and Igbo" (National Policy on Education, 1985).

\section{Section 2:11(3)}

"Government will ensure that the medium of instruction will be principally the Mother Tongue or the language of the immediate environment, and to the end will (a) develop the orthography for many more Nigerian languages, and (b) produce textbooks in Nigerian languages" (National Policy on Education, 1985).

\section{Section 3:15(4)}

"Government will see to it that the medium of instruction in the primary school is initially the Mother Tongue or the language of immediate environment and at a later stage, English"(National Policy on Education, 1985).

As pointed out by Adegbija (2004), section 4 of the policy deals with secondary education. It had no direct policy pronouncement on language use, but on the curriculum (Adegbija, 2004).The curriculum for the junior secondary school stipulated two Nigerian languages were to be studied as subjects in school while a Nigerian language should be studied as a subject for the senior secondary school.

Section 7of the policy mentioned language as a part of the General Studies component of the Teacher Training program. Sections 51 and 91 referred to the use of language in the National and States Houses of Assembly.

\section{Section 4:4}

The junior secondary school will be both pre-vocational and academic. It will be as free as possible and will teach all the basic subjects which will enable pupils to acquire further knowledge and develop skills. The curriculum should be structured as follows:

\begin{tabular}{|l|l|l|}
\hline Core Subjects & Pre-Vocational Subjects & Non-Vocational Subjects \\
\hline Mathematics & Woodwork & Arabic Studies \\
\hline English & Metal Work & French \\
\hline Nigerian Languages (2) & Electronics & \\
\hline Science & Mechanics & \\
\hline Social Studies & Local Crafts & \\
\hline Art and Music & Home Economics & \\
\hline Practical Agriculture & Business Studies & \\
\hline Religious and Moral Instruction & & \\
\hline Physical Education & & \\
\hline Pre-Vocational Subjects & & \\
\hline
\end{tabular}

(National Policy of Education, 1985, p. 17)

In selecting two Nigerian languages, students should study the language of their own area in addition to any of the three main Nigerian languages. The ability to deliver the instruction of Hausa, Igbo, and Yoruba are subject to availability of teachers (National Policy of Education, 1985).

\section{Section 4:6}

"The senior secondary school will be for those able and willing to have a complete six-year secondary education. It will be comprehensive but will have a core curriculum designed to broaden pupil's knowledge and outlook. The core curriculum outline is the following:

A. Core Subjects

1. English Language

2. One Nigeria Language

3. Mathematics

4. One of the following alternative subjects: Physics, Chemistry, and Biology

One of the following: Literature in English, History, and Geography

5. Agricultural Science or a Vocational Subject

These are the group of subjects, which every pupil must take in addition to his specialties" (National Policy of Education, 1985). 


\section{Section 7:52(6)}

"A new nation-wide emphasis will be placed on the study of Nigerian Arts and Culture. The National Commission will work the overall strategy for the inclusion of Nigerian Arts, Culture, and Languages in Adult Education Programs" (National Policy of Education, 1985).

\section{Section 51}

"The business of the National Assembly shall be conducted in English, Hausa, Igbo, and Yoruba when adequate arrangements have been made, therefore" (National Policy of Education, 1985).

\section{Section 91}

"The business of the House of Assembly will be conducted in English, but the House may in addition to English conduct the business in one or more languages spoken in the state as the House may be resolution approve(National Policy of Education, 1985). The above-mentioned provisions in the National Policy on Education is what is being referred to as Nigeria Language Policy document. According to Adegbija (2004), there is no other document specifically dedicated to language policy and language planning.

\section{Impact of Nigerian Language Policy on Minority Language Speakers}

Language is such an integral part of social life that government often consciously influences its use. According to Shohamy (2006) and García (2012),language policies are used globally as instruments through which citizens can be shaped and measured. Sociocultural membership can be granted or denied.Elusiveness of the status of minority languages has made speakers of any of the minority languages a second class-citizen in their own country.Language policies have the power to stigmatize other languages (Alegre, 2018). Tollefson (2013) argues that language policies are mechanisms for creating and sustaining systems of inequality that benefit wealthy and powerful individuals, groups, institutions, and nation-states.By elevating three major languages, as national languages, the government of Nigeria has further widened the inequality gap that already exist among speakers of the three major languages and the minority languages.

Furthermore, Coady \& Laoire (2002), Shohamy (2006)and Du Plessis (2012) stated that language policy is not always implemented in practice. There is a covert and implicit language planning hidden in language practices. This is in confirmation with the Nigeria language policy that is not implemented.There are discrepancies in the theory and practice. The government is nonchalant about these issues.In addition, the policy is vague about the time and manner of execution. It is not clear from the policy specification when and how the major languages should be implemented. The policy excludes the exact year of transition from Mother Tongue to English and what will happen to the indigenous languages after transition. Therefore, as stated by Sonntag (1995) and Tollefson (1993),language policyrepresents the disciplinary power of government who determines what languages should be accorded higher status. The government of Nigeria awarded higher status to the national languages at the detriment of minority languagesin order to endanger minority languages. Nigeria's language policy is used as a tool to legalize majority languageand prohibit minority languages.

\section{Conflict of Interest}

Since independence, Nigeria has been politically controlled by speakers of the major languages. Many of thePresidents and Heads of State arespeakers of the three major languages as illustrated inTable 1. They have every reason to promote their languages despite the sworn oath of office.Theinterest of these leaders in promoting their languages which is either one of the majority languages (Hausa, Yoruba or Igbo) is at variance and in conflict with their declaration of unity in diversity on the assumption of office. 
Table 1: Nigerian Leaders since Independence

\begin{tabular}{|l|l|l|}
\hline Time in Office & Name & Language Group \\
\hline $1960-1963$ & Prime Minister Abubakar Tafawa Balewa & Hausa \\
\hline $1963-1966$ & President Nnamdi Azikiwe & Igbo \\
\hline 1966 & Major General Johnson Aguiyi-Ironsi & Igbo \\
\hline $1966-1975$ & General Yakubu Gowon & Minority Language \\
\hline $1975-1976$ & General Murtala Mohammed & Hausa \\
\hline $1976-1979$ & General Olusegun Obasanjo & Yoruba \\
\hline $1979-1983$ & President Shehu Shagari & Hausa/Fulfulde \\
\hline $1983-1985$ & Major-General Muhammadu Buhari & Hausa/Fulfulde \\
\hline $1985-1993$ & General Ibrahim Babangida & Hausa \\
\hline $1993-$ & President Ernest Shonekan & Yoruba \\
\hline $1993-1998$ & General Sani Abacha & Hausa \\
\hline $1998-1999$ & General Abdulsalami Abubakar & Yoruba \\
\hline $1999-2007$ & President Olusegun Obasanjo & Yoruba \\
\hline $2007-2010$ & President UmaruMusa Yar'Adua & Hausa \\
\hline $2010-2015$ & President Goodluck Jonathan & Minority Language \\
\hline $2015-P r e s e n t$ & President Muhammadu Buhari & Hausa/Fulfude \\
\hline
\end{tabular}

Every president of the Federal Republic of Nigeria sworean oath on assumption of office saying:

"I, ..... do solemnly swear/affirm that I will be faithful and bear true allegiance to the FederalRepublic of Nigeria; that as President of the Federal Republic of Nigeria, I will discharge my duties to the best of my ability, faithfully and in accordance with the Constitution of the Federal Republic of Nigeria and the law, and always in the interest of the sovereignty, integrity, solidarity, well-being and prosperity of the Federal Republic of Nigeria; that I will strive to preserve the Fundamental Objectives and Directive Principles of State Policy contained in the Constitution of the Federal Republic of Nigeria; that I will not allow my personal interest to influence my official conduct or my official decisions; that I will to the best of my ability preserve, protect and defend the Constitution of the Federal Republic of Nigeria; that I will abide by the Code of Conduct contained in the Fifth Schedule to the Constitution of the Federal Republic of Nigeria; that in all circumstances, I will do right to all manner of people, according to law, without fear or favour, affection or ill-will; that I will not directly or indirectly communicate or reveal to any person any matter which shall be brought under my consideration or shall become known to me as President of the Federal Republic of Nigeria, except as may be required for the due discharge of my duties as President; and that I will devote myself to the service and well-being of the people of Nigeria. So, help me God" (Seventh Schedule Oaths, 2019).

Every president swore to faithfully discharge his duty in accordance to the constitution. Section 2:11(3) of the constitution of the Federal Republic of Nigeria states that government will ensure that the medium of instruction in primary schools will be principally the Mother Tongue or the language of the immediate environment, and to the end will (a) develop the orthography for many more Nigerian languages, and (b) produce textbooks in Nigerian languages (National Policy on Education, 1985). Most minority languages are without orthographies and there are no textbooks inminoritylanguages. The medium of instruction in most public schools is English and not the Mother Tongue as contained in the language policy.

Section 3:15(4) of the constitution states, "The government will see to it that the medium of instruction in the primary school is initially the Mother Tongue or the language of immediate environment and at a later stage, English" (National Policy on Education, 1985).The statement, above,is vague. It is just a gimmick as none of the provisions has been implemented since the policy was formulated.The policy does not state the stage at which the medium of instruction will be transitioned from Mother Tongue to English. Nigeria's language policy is a tool used by the government to legalize majority languages and strategically prohibit minority languages, so they can be extinct over time.According to Wright (2007), once one language has been adopted, it ousts the other languages.Speakers of the minority languages cannot be coaxed by the language policy. Every citizen of Nigeria has a right to his or her language.

Although Nigeria language policy did not force minority speakers to drop their languages, the policy states that children of minority language speakers should learn any of the major languages inaddition to their Mother Tongue. This part of the language policy endangers minority languagesespecially for the younger generation.A language is endangered when its use is restricted. Therefore, minority languages are programmed by the policy for extermination.Minority languages are not protected or promoted.Efik, Ibibio, Edo, Izon and the three national languages are promoted in the media. 
For example, many minority languages are not promoted in the court, judicial system and formaleducation. The use of the minority languagesisdrastically reduced. Minority languages have no status.

Abrams \& Strogatz (2003) demonstrated how languages without enough social or economic status are bound to be extinct if threatened by a powerful foreign language. Minority languages in Nigeria are threatened by the majority languages as well as the powerful dominant foreign language such as English. English is the official language of Nigeria.Skutnabb-Kangas (2002) explains how minority children, who are educated in the dominant language as the medium of instruction in schools, are not likely to speak their indigenous language to their children. The indigenous language disappears after two or three generationsdue to the lack of use (Skutnabb-Kangas, 2002).

Nettle\& Romaine (2000) have predicted the disappearance of many of the world's endangered languages within this century. Most of these endangered languages are indigenous languages whose statusesare insignificant. Language endangerment is a widespread phenomenon among minority languages.

\section{Conclusion}

This paper presents the conflict of interest in the language policy of Nigeria. The government and policy makers have already programmed the minority languages for extinction in the near future. Elevating the status of three languages because of the number of speakers is not the solution to Nigeria's numerous challenges. Every language has the potential of becoming a national language irrespective of the number of speakers. Orthographies should be provided for minority languages in order to protect them from extinction. If the intention of government is to promote unity in diversity, then government should provide instructional materials in minority languages. The extinction of minority languages, which have been endangered by the language policy, will result in the loss of the identity and cultural heritage of its minority speakers.It is the minority languages that help to identify the minority speakers. Government should promote minority languages in the media, judiciary, and education.

\section{References}

Abrams, D. M. \& Strogatz, S. H. (2003). Modelling the Dynamics of Language Death.Nature, 424, 900.

Adegbija, E. (2004). Language Policy and Planning in Nigeria. Current Issues in Language Planning, 5(3), 181-246.

Akinnaso, N. (1990). The Politics of Language Planning in Education in Nigeria. Word41(3), 337-367.

Ayankanmi, A. (1966). The Missionary Impact on Modern Nigeria, 1842-1914: A Political and Social Analysis. London: Longmans.

Bamgbose, A. (1971).MotherTongue Education: The West Africa Experience. Paris: UNESCO.

Coady, M. \&Laoire, M.O. (2002). Mismatches in Language Policy and Practice in Education: The case of Gaelscoileanna in the Republic of Ireland. Language Policy, 1: 143-158.

Cooper, R. L. (1989). Language Planning and Social Change. Cambridge: Cambridge University Press.

Crawford, J. (2017). Language Policy.” Retrieved on 2/25/17, at www.languagepolicy.net/archieves/langpol.htm

Du Plessis, T. 2012. The Role of Language Policy in Linguistic Landscape Changes in a Rural Area of the Free State Province of South Africa. Language Matters, 43(2), 263- 282.

Fisher, J. A. (1973). Language Modernization and Planning in Comparison with other types of National Modernization and Planning. Language in Society, 2, 23-42.

García, O. 2012. Ethnic Identity and Language Policy. In B. Spolsky (Ed.). The Cambridge handbook of language policy (p. 79-99). Cambridge: Cambridge University Press

Gordon, R. (2017). Ethnologue: Languages of the World. Retrieved on 3/25/2017 from http://ethnologue.com

Ibekwe, J. (2006). Educational Language Policy in Nigeria: A Critical Analysis. Retrieved on 3/13/2017 at http://digitalcommons.uconn.edu/dissertations/AA/3915543

National Policy on Education (1985) Lagos: Federal Government Press.

Nettle, D. \& Romaine, S. (2000). Vanishing Voices: The Extinction of the World's Languages. New York: Oxford University Press.

Robin, J. \& Jernudd, B. (1971). Can Language be Planned? Sociolinguistic Theory and Practice for Developing Nations. Honolulu: University Press.

Seventh ScheduleOaths. Oaths of Office of President. Retrieved on 09/27/2019 at https://nigerianconstitution.com/seventh-schedule-oaths-oath-of-office-of-president/

Shohamy, E. (2006). Language Policy: Hidden Agendas and New Approaches. London and New York: Routledge.

Skutnabb-Kangas, T. (2002). Marvelous Human Rights Rhetoric and Grim Realities: Language Rights in Education. Journal of Language, Identity, and Education, 1, 179-205. 
Sonntag, S. K. (1995). Elite Competition and Official Language Movements. In J. Tollefson, (Ed.). Power and Inequality in Language Education (p. 91-111). Cambridge: Cambridge University Press.

Spolsky, B. (2004). Language Policy. Cambridge: Cambridge University Press.

Tollefson, J. (1993). Language Policy and Power: Yugoslavia, the Philippines, and Southeast Asian Refugees in the United States. International Journal of the Sociology of Language, 103(1), 73-95.

Tollefson, J. W. (2013). Language Policy in a time of Crisis and Transformation. In J. Tollefson (Ed.), Language Policies in Education: Critical issues (pp. 3-15). Mahwah, NJ: Lawrence Erlbaum Associates.

Tondo, S. (2017). Language Teaching and Language Policy in Nigeria." Retrieved on 2/25/17 2017 at http://ssrn.com/abstract $=1896330$

Wright, S. (2007). The Rights to Speak One's Language: Reflections on Theory and Practice. Language Policy, 6, 203224.

Zakaria, F. (2016). National Language \& Minority Language Rights.Englisia, 4, (1), 55-65. 